\title{
A Study of Myoepithelial Cells in Fine Needle Aspirates from Breast Lump Using Antibody to p63
}

\author{
Pooja Agarwal ${ }^{1 *}$, Prashant Prakash ${ }^{2}$, Trishala Bhadhkaria ${ }^{1}$, Shwetank Prakash ${ }^{3}$, Ravishankar Bhagat ${ }^{4}$ \\ ${ }^{1}$ Department of Pathology, S.N. Medical College, Agra. India \\ ${ }^{2}$ Superspeciality Unit of Pulmonary Medicine, Department of Medicine, S.N. Medical College, Agra. India \\ ${ }^{3}$ Department of General Surgery, S.N. Medical College, Agra, India \\ ${ }^{4}$ Department of Medicine, S.N. Medical College, Agra, India
}

\begin{abstract}
Background: Myoepithelial cells of the mammary gland are considered to be a key in distinguishing benign from malignant disease in fine-needle aspiration cytology (FNAC). p63 decorates the nuclei of myoepithelial cells. In view of this, present study was undertaken to study the difference in number of myoepitheal cells in various breast lesions using anti p63 immunocytochemistry.

Methods: This study was conducted on 50 patients presenting with breast lump. FNA was done, smears prepared were stained with May Grunwald Giemsa and subjected to immunocytochemistry for p63. MGG stained smears were subjected to quantitative estimation of myoepithelial cells per 1000 ductal cells. Percentage of cell clusters showing p63 positive cells were noted. Only the nuclear immunoreactivity for p63 was considered specific.

Result: Maximum number of cases (26) were in 20 - 29 years age group (55.3\%). The mean number of myoepithelial cells in the benign lesions was 196.8 while ductal carcinoma had a mean of 5.8.The difference between the mean of myoepithelial cells/1000 ductal cells was found to be statistically significant (t- value 4.51 and p-value .000048 ). The difference in p63 immunostaining between benign and malignant lesions was also found to be statistically significant (for positivity of p63 at $0 \%$ and $>75 \% \mathrm{p}$ value $<0.001$ ).

Conclusion: We hereby conclude that myoepithelial cells are a key to distinguish benign from malignant lesions in FNAC. Their sensitivity is increased by staining with p-63 antibody. We also conclude that presence of more than $74 \%$ positive cell clusters is strongly suggestive of benign lesions.
\end{abstract}

\section{Keywords: Breast Aspirates, Myoepithelial Cells, p63 antibody.}

\section{Introduction}

Breast diseases are common affliction of the females. About $30 \%$ of females suffer from benign breast disorders and require treatment in their life. Breast lump is a common presentation in the surgical outpatient clinic and majority have benign breast diseases. ${ }^{[1,2]}$

Myoepithelial cells of the mammary glands are considered to be a key in distinguishing benign from malignant disease in fine-needle aspiration cytology (FNAC). The identification of myoepithelial cells has been investigated using p63 antibodies. ${ }^{[3]}$ p63 is a homologue of p53 normally expressed in stratified epithelia like skin, tonsil, esophagus, and exocervix. It decorates the nuclei of myoepithelial cells, thereby overcoming the cytoplasmic fragility of myoepithelial cells in fine needle aspirates. Therefore it is better than other myoepithelial cell markers (calponin, h-caldesmon, maspin and CD10) that decorate either the cytoplasm or cytoplasm and nucleus of the myoepithelial cells. In view of this, present study was undertaken to study the difference in number of myoepitheal cells in aspirates from various breast lesions using anti p63 immunocytochemistry staining for myoepithelial cells and to establish the diagnostic utility of myoepithelial cells in various breast lesions

\section{Materials and Methods}

This study was conducted in department of pathology on 50 patients presenting with breast lump during Jan 15- June 15. The patient consent was taken. The patient was placed in supine position for needle aspiration. The lump was palpated and overlying skin was thoroughly cleaned with antiseptic solution. A 22 or 23 gauge needle (1 to 1.5 inch long) with $20 \mathrm{ml}$ syringe was used for aspiration. Smears were prepared for May Grunwald Giemsa staining as well as immunocytochemistry. Subsequently MGG stained smears were subjected to quantitative estimation of myoepithelial cells per 1000 ductal cells. At least 20 HPF were scanned and area with least overlapping of cells was selected.

Slides were stained for p63 (monoclonal mouse antihuman p63 protein clone DAK-p63 ready to use by DAKO was used.) and care was taken to ensure that the slides did not dry at any step of the staining as it can lead to false negative results. Slides were immersed for $5 \mathrm{mins}$ in Phosphate 
buffer solution (PBS) and then peroxide block reagent was applied for five minutes. Slides were again washed in PBS solution for three minutes and power block reagent applied for five minutes followed by primary antibody solution (anti p 63 ) for 30-40 minutes. They were again immersed in PBS solution for 30 minutes. Then secondary antibody was applied for 30 minutes and slides again washed in PBS solution for 6 minutes. Smear was covered with the DAB solution for 10 minutes and then washed in running tap water for 3 minutes followed by counter staining with hematoxylin for 5 minutes. Slides were again washed in running tap water for few minutes. The slides were then immersed in $80 \%$ isopropyl alchohol for few minutes in coplin jar followed in $100 \%$ isopropyl alchohol for few minutes. Percentage of cell clusters showing p63 positive cells were noted. Only the nuclear immunoreactivity for p63 was considered specific. Cytoplasmic and membranous staining was considered nonspecific. The non-parametric Mann-Whitney rank sum test was applied to find statistical difference in the results.

\section{Result}

50 cases were included in this study. After excluding 3 cases which were inadequate aspirate composed of red blood cells and adipose tissue only; 47 cases were evaluated for the study. Cases with the diagnosis of acute mastitis, breast abscess, fat necrosis and galactocele were not included in the study as they had no or very scanty breast epithelial and myoepithelial cells. The cases were between 17 - 69 years of age, youngest being 17 years old and oldest being 69 years old. Maximum number of cases (26) were in 20 - 29 years age group (55.3\%)[Table 1]. Out of 47 cases, 08 cases $(17 \%)$ were malignant and 39 cases $(83 \%)$ were benign. The age of patients with benign diagnosis ranged from 17 to 62 years with majority of cases between $20-29$ yrs $(66.7 \%)$. The age group of malignant cases was between 35 to 69 years. Maximum number of cases fell between 50 - 59 years $(37.5 \%)$.No case of malignancy was seen in patients younger than 35 years. Out of 47 cases, maximum number of cases (27) were of fibroadenoma (57.4\%). Invasive Ductal carcinoma (08 cases) constituted 17\% [Table 2]. Out of 39 benign lesions, only 6 cases $(15.4 \%)$ were $>5 \mathrm{~cm}$ in size while 4 cases $(50 \%)$ of malignancy lesions were $>5 \mathrm{~cm}$ in size. Out of 47 cases, 32 were left sided (68\%).
Myoepithelial cells were counted as cells with same or smaller size than that of epithelial cells with bipolar shape, dense, homogenous chromatin, smooth nuclear outline without any nucleoli, stripped cytoplasm, distributed within the epithelial clusters or scattered singly in the background. Their mean/1000 ductal cells was calculated. The mean number of myoepithelial cells in the benign lesions was 196.8. The cases of benign breast disease with non-specific descriptive diagnosis had the maximum number of myoepithelial cells (359.1) followed by fibroadenoma(161.1) and granulomatous mastitis (92). The ductal carcinoma had very less number of myoepithelial cells with a mean of 5.8.The difference between the mean of myoepithelial cells/1000 ductal cells in benign and malignant lesion was found to be statistically significant (t- value 4.51 and p-value .000048)[Table 3].

Stained slides were then evaluated for p63 antibody status. Percentage of cell clusters showing p63 positive cells were noted. Only the nuclear immunoreactivity for p63 was considered specific. Cytoplasmic and membranous staining was considered nonspecific. 20 cases $(74 \%)$ of fibroadenoma showed p63 positivity in more than $75 \%$ cell clusters, 4 cases $(14.8 \%$ )showed p63 positivity in $51-75 \%$ cell clusters, 2 cases $(7.4 \%)$ showed p63 positivity in 26$50 \%$ and 1 case $(3.7 \%)$ showed p63 positivity in $20 \%$ cell clusters(Figure 1). In 7cases (77.7\%) of benign breast lesions with non-specific descriptive diagnosis, p63 positivity was seen in more than $75 \%$ cell clusters and 2 cases $(22.2 \%)$ showed p63 positivity in $51-75 \%$ cell clusters(Figure 2). In Phyllodes tumor (borderline) no p63 positivity was seen (Figure 3). 1 case (12.5\%) of Ductal carcinoma showed p63 positive cells in less than $25 \%$ cell clusters. Rest 7 cases $(87.5 \%)$ did not show any p63 positivity (Figure 4) [Table4].

So in benign lesions 27 cases $(69.2 \%)$ showed p63 staining in more than $75 \%$ cell clusters, 6 cases $(15.3 \%)$ showed positivity in $51-75 \%$ cell clusters, 2 cases $(5.1 \%)$ showed $26-50 \%$ p63 positive cell clusters, 2 cases (5.1\%) had $1-25 \%$ p63 positive cell clusters and 2 cases (phyllodes tumor) showed no positivity for $\mathrm{p} 63$. In malignant lesions only 1 case $(12.5 \%)$ showed p63 positive cells in less than $25 \%$ cell clusters. The difference between benign and malignant lesions was found to be statistically significant (for positivity of $\mathrm{p} 63$ at $0 \%$ and $>75 \% \mathrm{p}$ value $<0.001$ ).

Table 1: Distribution of Cases According to Age

\begin{tabular}{|c|c|c|c|}
\hline S.NO. & Age (in years) & No. of cases & Percentage \\
\hline 1 & $10-19$ & 02 & $4.2 \%$ \\
\hline 2 & $20-29$ & 26 & $55.3 \%$ \\
\hline 3 & $30-39$ & 07 & $14.9 \%$ \\
\hline 4 & $40-49$ & 05 & $10.6 \%$ \\
\hline 5 & $50-59$ & 04 & $8.5 \%$ \\
\hline 6 & $60-69$ & 03 & $6.4 \%$ \\
\hline
\end{tabular}


Table 2: Distribution of Cases According to Diagnosis

\begin{tabular}{|c|c|c|}
\hline Diagnosis & No. of cases & Percentage \\
\hline Granulomatous Mastitis & 01 & $2.1 \%$ \\
\hline Fibroadenoma & 27 & $57.4 \%$ \\
\hline $\begin{array}{l}\text { Benign Breast Lesion with non-specific descriptive } \\
\text { diagnosis }\end{array}$ & 09 & $19.1 \%$ \\
\hline Phyllodes Tumor (borderline) & 02 & $4.2 \%$ \\
\hline Invasive Ductal Carcinoma & 08 & $17 \%$ \\
\hline
\end{tabular}

Table 3: Mean of Myoepithelial Cells / 1000 Ductal Cells in Benign and Malignant Lesions

\begin{tabular}{|l|l|c|}
\hline \multicolumn{1}{|c|}{ S.No } & \multicolumn{1}{|c|}{ BENIGN } \\
\hline \multicolumn{1}{|c|}{ Mesions } \\
\hline 1 & Fibroadenoma $\mathrm{n}=27$ & 161.1 \\
\hline 2 & Benign Breast Lesions with non specific descriptive diagnosis $\mathrm{n}=9$ & 359.1 \\
\hline 3 & Granulomatous mastitis $\mathrm{n}=1$ & 92 \\
\hline 4 & $\begin{array}{l}\text { Phyllodes tumour } \mathrm{n}=2 \\
\text { (borderline) }\end{array}$ & 0 \\
\hline & Average number of myoepithelial cells in benign lesions & 196.8 \\
\hline 1 & & \multicolumn{2}{|c|}{ MALIGNANT } \\
\hline
\end{tabular}

$t$-value 4.51 and p-value .000048 .

Table 4: percentage of p63+ cell clusters in breast lesions.

\begin{tabular}{|c|c|c|c|c|c|}
\hline Benign lesions & $0 \%$ & $1-25 \%$ & $26-50 \%$ & $51-75 \%$ & $>75 \%$ \\
\hline Fibroadenoma $n=27$ & 0 & $1(3.7 \%)$ & $2(7.4 \%)$ & $4(14.8 \%)$ & $20(74 \%)$ \\
\hline $\begin{array}{l}\text { Benign breast lesions with non-specific } \\
\text { descriptive diagnosis } n=9\end{array}$ & 0 & 0 & 0 & $2(22.2 \%)$ & $7(77.7 \%)$ \\
\hline Phyllodes tumor (borderline) $n=2$ & $2(100 \%)$ & 0 & 0 & 0 & 0 \\
\hline Granulomatous mastitis $n=1$ & 0 & $1(100 \%)$ & 0 & 0 & 0 \\
\hline Invasive Ductal carcinoma $\mathrm{n}=8$ & $7(87.5 \%)$ & $1(12.5 \%)$ & 0 & 0 & 0 \\
\hline
\end{tabular}

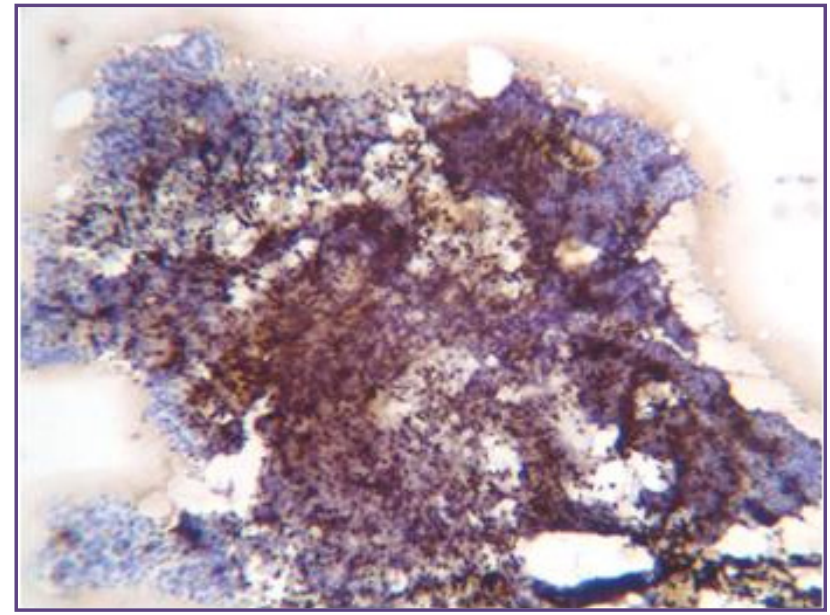

Fig. 1: Fibroadenoma showing p63 nuclear staining in myoepithelial cells(p63 ICC 100x).

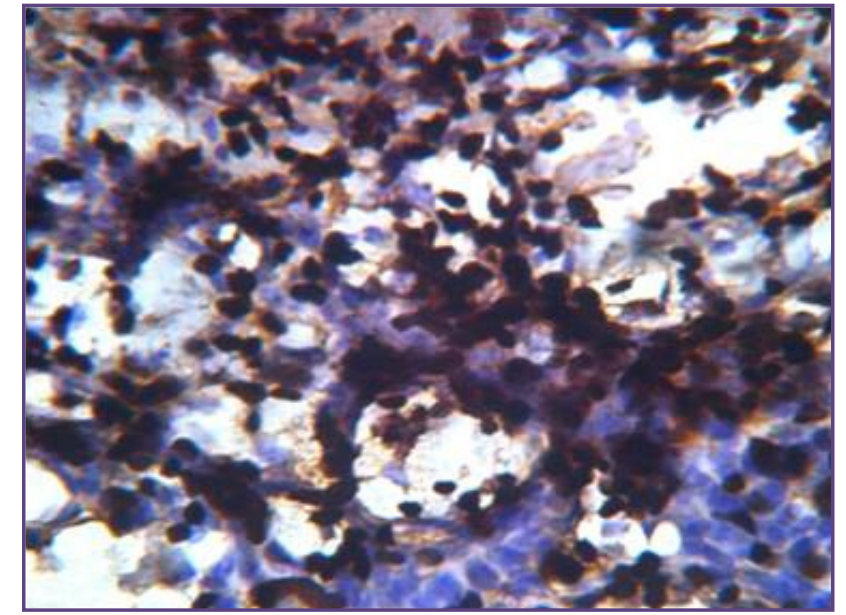

Fig. 2: Benign Breast Disease with non-specific descriptive diagnosis showing p63 nuclear staining in myoepithelial cells (p63 ICC, 400x). 


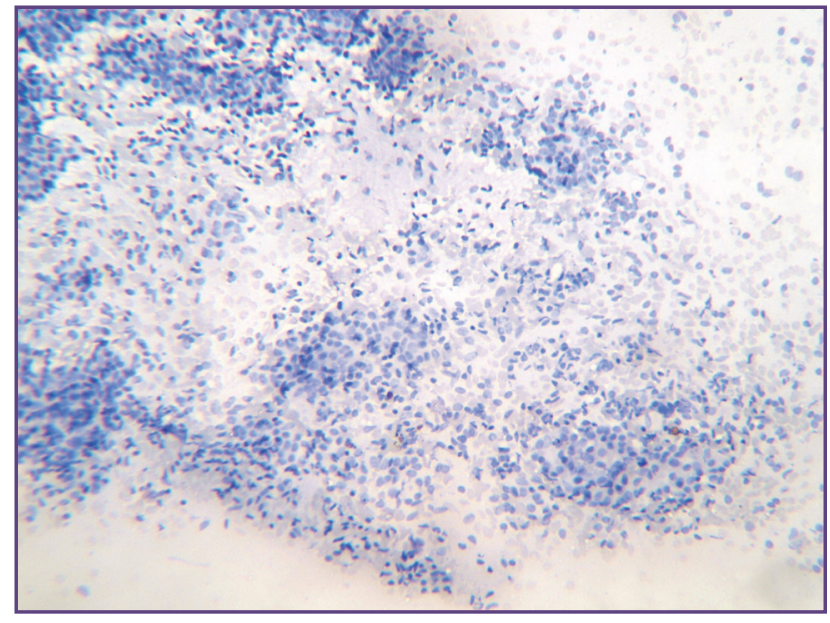

Fig. 3: Borderline Phyllodes tumor showing p63 negative staining (p63 ICC 100x).

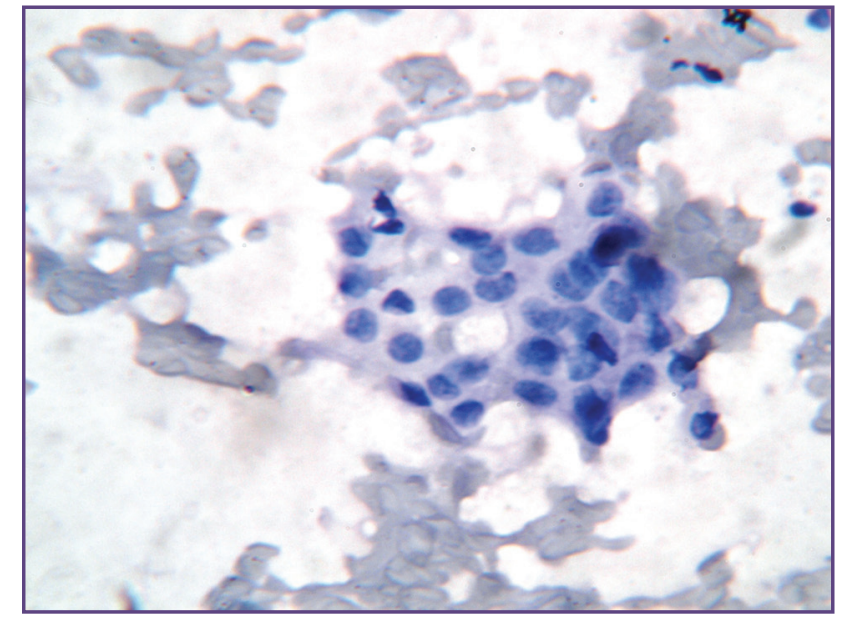

Fig. 4: Invasive Ductal carcinoma showing p63 negative staining (p63 ICC 400x).

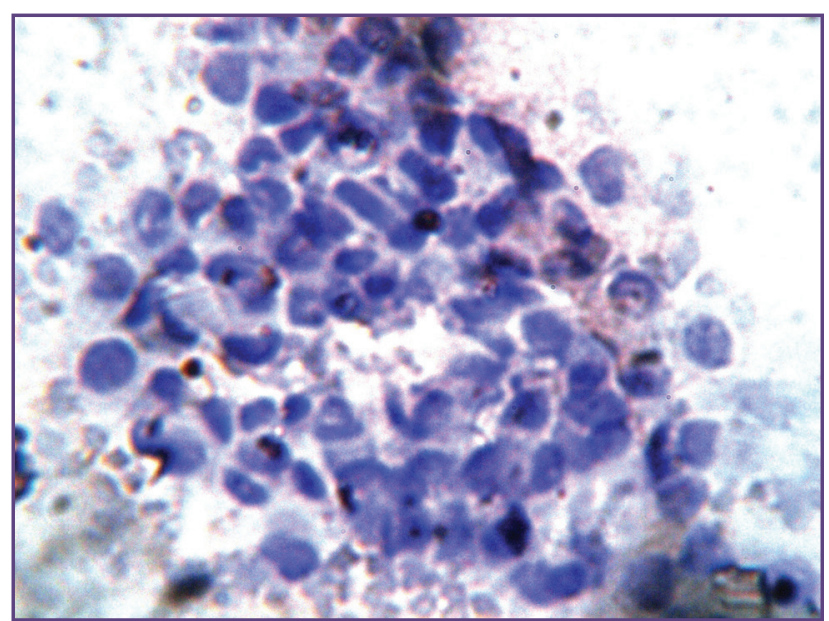

Fig. 5: Invasive Ductal carcinoma showing p63 positive cells (P63 ICC 400x).

\section{Discussion}

In routine cytologic preparation, the precise identification of myoepithelial cells plays a major role in the diagnostic assessment of several types of breast lesions. In the present study $6 \%$ cases were inadequate. Our finding is concordant with Jayaram $\mathrm{G}$ et $\mathrm{al}^{[4]}$ and PB Jarwani et al ${ }^{[5]}$ who also found inadequate samples to be $7.43 \%$ and $4.5 \%$ respectively. In our study, maximum number of cases was in 20-29 years which is in concordance with the result of the studies by Modi P et al, al[6] Singh A et al, ${ }^{[7]}$ Chaudhury $\mathrm{S}$ et al, ${ }^{[8]}$ Likhar KS et al, ${ }^{[9]}$ Thakkar B et al. ${ }^{[10]}$ Maximum number of benign cases was in the age group of 20-29 years which is near similar to the findings of Modi $\mathrm{P}$ et al, ${ }^{[6]}$ Likhar KS et al, ${ }^{[9]}$ Rahman MZ et al ${ }^{[1]}$ and Thakkar B et al. ${ }^{[10]}$ Maximum number of malignant cases fell between 50-59 years. Our finding are in concordance with studies of A Singh et al,,${ }^{[7]}$ Bukhari MH et al, ${ }^{[12]}$ Chaudhury S et al, ${ }^{[8]}$ Likhar KS et al ${ }^{[9]}$ while slightly lower age group of 41-50yrs was noted by Thakkar B et al. ${ }^{[10]}$

In our study, $83 \%$ cases were benign which is close to the finding of Chaudhury $\mathrm{S}$ et al ${ }^{[8]}(80.77 \%)$ while Modi $\mathrm{P}$ et al, ${ }^{[6]}$ Bukhari MH et al, ${ }^{[12]}$ Thakkar B et al ${ }^{[10]}$ found lower percentage of benign cases i.e. $72 \%, 60 \%, 54.16 \%$ respectively. This could be probably because they had additional categories of suspicious for malignancy and benign with atypia. Our study did not include these categories. In our study $17 \%$ cases were malignant which is near similar to the findings of Modi P et al ${ }^{[6]}$ Chaudhury S et al, ${ }^{[8]}$ Rahman MZ et al ${ }^{[1]]}$ as their reported rates of malignancy were $16.7 \%, 19.23 \%$ and $14.17 \%$ respectively.

Fibroadenoma (57.4\%) was the major cause of the breast lump in this study which is similar to the findings of Nagao $\mathrm{T}$ et a ${ }^{[3]}$, Modi P et al ${ }^{[6]}$, Bukhari MH et al ${ }^{[12]}$, Rahman MZ et al ${ }^{[11]}$. 
$50 \%$ of malignant cases had a lump were of size more than $5 \mathrm{~cm}$ which is much similar to the study of Ballo et al, ${ }^{[13]}$ who reported that in maximum of number of malignant cases $(78.3 \%)$ lump size was more than $2 \mathrm{~cm}$. In the present study $66 \%$ cases were left sided. Hussain MT et al ${ }^{[14]}$ also observed similarly that left breast (54\%) was involved more commonly than the right (46\%).

Mean of Myoepithelial cells /1000 ductal cells in benign lesions was 196.8 while ductal carcinoma had very less number of myoepithelial cells with a mean of 5.8. Pattari SK et $\mathrm{al}^{[15]}$ reported the number of myoepithelial cells/1000 ductal cells as 5.1,30.8,28.3 and 38.4 mean in malignant, carcinoma in situ, proliferative breast disease and benign breast disease respectively. We observed higher mean value of myoepithelial cells in benign lesions, however the number of myoepithelial cells in ductal carcinoma was concordant with the observation of Pattari SK et al. ${ }^{[15]}$ They found statistically significant difference between the benign and malignant ( $p$-value $<.0001)$ which is concordant with the present study.

In our study $69.2 \%$ benign cases showed p63 staining in more than $75 \%$ cell clusters, $15.3 \%$ showed $51-75 \%$ p63 positive cell clusters, $5.1 \%$ showed $26-50 \%$ p63 positive cell clusters and $5.1 \%$ cases had $1-25 \%$ p63 positive cell clusters. Phyllodes tumor showed no positivity for p63. In malignant lesions only $12.5 \%$ cases showed p63 positive cells in less than $25 \%$, while in the study of Anthony M. Harton et al ${ }^{[16]} 10.3 \%$ benign cases showed p63 staining $>74 \%$ cell clusters, $41.3 \%$ cases showed 50 $74 \%$ p63 positive cell clusters, $20.6 \%$ cases showed $24-$ $49 \%$ p63 positive cell clusters, $13.7 \%$ cases had $1-25 \%$ p63 positive cell clusters and $13.7 \%$ cases showed no positivity for $\mathrm{p} 63$. In malignant lesions $11.7 \%$ cases showed p63 positive cells in less than $25 \%$ cell clusters and there ( $p$-value was $<.0001)$ which is concordant with our study $(\mathrm{p}$-value $<.0001)$.

Aiad H.A.S. et $\mathrm{al}^{[17]}$ also found that $75 \%$ benign cases showed p63 positivity and $11 \%$ cases of malignant cases showed p63 positivity. Barbareschi $\mathrm{M}$ et al ${ }^{[18]}$ also concluded that p63 is a reliable, highly specific, and sensitive marker for myoepithelial cells in both histologic and cytologic preparation to differentiate between benign and malignant cases. Stefanou D et al ${ }^{[19]}$ also studied that all benign cases were positive for p63 immunostaining in myoepithelial cell while all invasive carcinomas were devoid of p63 staining.

In our study phyllodes tumor showed no positivity for p63 which is concordant with the study of Koker MM et al ${ }^{[20]}$ who also observed that phyllodes tumor were consistently negative for p63 expression.

\section{Conclusion}

We hereby conclude that myoepithelial cells are a key to distinguish benign from malignant lesions in fine needle aspiration cytology. Their sensitivity is increased by staining with p-63 antibody. Benign and malignant breast lesions showed significantly different staining pattern for p63 (p-value <.0001). Thus p63 is a reliable nuclear marker of myoepithelial cells in breast cytology and when used in conjuction with morphologic examination it may be useful in categorizing problematic cases. We also conclude that presence of more than $74 \%$ positive cell clusters is strongly suggestive of benign lesions.

\section{Reference}

1. Sainsbury R. The breast. In: Norman S. Williams, Christopher J.K. Bulstrode, P. Ronan O'Connell, editor. Bailey and Love's short practice of surgery, 25e: Edward Arnold; 2008.p-831.

2. Chianakwalam CI, Bates T: Diagnosis and management of breast lump. Surgery (2001); 19:73-76.

3. Nagao T, Bando Y, Sasa M, et al : False-positives in fine needle aspiration cytology of breast disease can be reduced with p63 immunostaining. Anticancer Res2006;26:4373-7.

4. Jayaram G, Alhady SF, Yip CH . Cytological analysis of breast lesions: A review of 780 cases. Malaysian J Pathol 1996; 18: 81-7.

5. Jarwani PB, Patel DC, Patel SM, et al. Fine needle aspiration cytology in a palpable breast lump GCSMC J Med Sci2013;2(2): 12-16.

6. Modi P, Oza H, Bhalodia J. Fnac as preoperative diagnostic tool for neoplastic and non-neoplastic breast lesions: A teaching hospital experience. National Journal of Medical Research 2014; 4(4): 274-278.

7. Singh A, Haritwal A, Murali B . Pattern of breast lumps and diagnostic accuracy of fine needle aspiration cytology, A hospital based study from Pondicherry, India. The Internet Journal of Pathology. 2010;11:2.

8. Chaudhury S, Alam MK, Haque MS. The role of FNAC in diagnosis of breast disease at different ages -208 cases. Journal of Bangladesh College of Physicians and Surgeons 2012; 30(3): 137-140.

9. Likhar KS, Fatima A, Hazari R A, et al. Diagnostic role of fnac in breast lesions IJRRMS 2013;3(1):12-14.

10. Thakkar B, Parekh M, Trivedi NJ et al. Role of fine needle aspiration cytology in palpable breast lesions and its correlation with histopathological diagnosis .National Journal of Medical Research 2014;4(4):283-288.

11. Rahman MZ, Islam S. Fine needle aspiration cytology of palpable breast lump: A study Of 1778 cases. Surgery: Current Research 2013 S12: 001.

12. Bukhari MH, Arshad M, Jamal S et al. Use of fine needle aspiration in the evaluation of breast lumps. Pathology Research International. 2011; 1-10. 
13. Ballo MS, Sneige N. Can core needle biopsy replace fineneedle aspiration, cytology in the diagnosis of palpable breast carcinoma : A comparative study of 124 women, Cancer 1996; 78: 773-7.

14. Hussain MT. Comparison of fine needle aspiration cytology with excision biopsy of breast lump. J Coll Physicians Surg Pak 2005:15:211-4.

15. Pattari SK, Dey P, Gupta SK, et al. Myoepithelial cells: Any role in aspiration cytology smears of breast tumours. Cytojournal 2008; 5:9.

16. Harton AM, Wang HH, Schnitt SJ, et al. p63 Immunocytochemistry improves accuracy of diagnosis with fine-needle aspiration of the breast. Am J Clin Pathol 2007; 128: 80-5.
17. Aiad HAS, Abd El-Halim Kandil M . Diagnostic role of p63 immunostaining in fine needle aspiration cytology of different breast lesions. Acta Cytol 2011; 55149-57

18. Barbareschi M, Pecciarini L, Cangi MG et al. p63, a p53 homologue, is a selective nuclear marker of myoepithelial cells of the human breast. Am J Surg Pathol. 2004; 28 :1506-12.

19. Stefanou D, Batistatou A, Nonni E. et al. P63 expression in benign and malignant breast lesions. Histol Histopathol 2004; 19:465-471.

20. Koker MM, Kleer CG. p63 expression in breast cancer: a highly sensitive and specific marker of metaplastic carcinoma. Am J Surg Pathol. 2004; 28 :1506-1512.

*Corresponding author:

Dr. Pooja Agarwal, 79, Gandhi Nagar, Bye Pass Road, Agra. 282003 INDIA

Phone: +91 9897627995

Email: drpooja.agarwal@gmail.com

Date of Submission : 04.10.2016

Date of Acceptance : 19.12.2016

Financial or other Competing Interests: None.
Date of Publication : 19.02.2017 